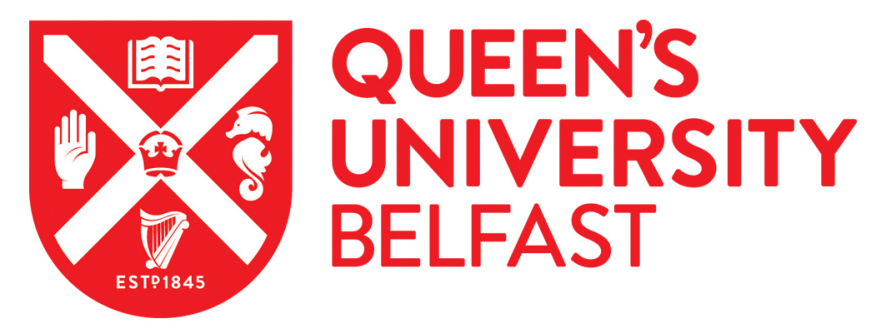

\title{
Catchment and in-stream influences on metal concentration and ochre deposit density in upland streams, Northern Ireland
}

Macintosh, K. A., \& Griffiths, D. (2013). Catchment and in-stream influences on metal concentration and ochre deposit density in upland streams, Northern Ireland. Environmental Earth Sciences, 70(7), 3023-3030. https://doi.org/10.1007/s12665-013-2363-6

\section{Published in:}

Environmental Earth Sciences

\section{Document Version:}

Peer reviewed version

Queen's University Belfast - Research Portal:

Link to publication record in Queen's University Belfast Research Portal

\section{Publisher rights}

Copyright Springer-Verlag Berlin Heidelberg 2013.

The final publication is available at Springer via http://dx.doi.org/10.1007/s12665-013-2363-6.

\section{General rights}

Copyright for the publications made accessible via the Queen's University Belfast Research Portal is retained by the author(s) and / or other copyright owners and it is a condition of accessing these publications that users recognise and abide by the legal requirements associated with these rights.

Take down policy

The Research Portal is Queen's institutional repository that provides access to Queen's research output. Every effort has been made to ensure that content in the Research Portal does not infringe any person's rights, or applicable UK laws. If you discover content in the Research Portal that you believe breaches copyright or violates any law, please contact openaccess@qub.ac.uk. 
1 Catchment and in-stream influences on metal concentration and ochre deposit density

2 in upland steams, Northern Ireland.

3

4

5 Katrina Ann Macintosh ${ }^{\text {a,* }} \cdot$ David Griffiths ${ }^{\text {a }}$

6 a School of Environmental Sciences, University of Ulster, Coleraine, U.K. BT52 1SA

7

$8 \quad{ }^{*}$ Corresponding author:

$9 \quad$ E-mail address: ka.macintosh@ulster.ac.uk

10 Tel.: +44 (0) 2870124426

11 Fax: +44 (0) 2870124911

12 


\section{Abstract}

14

Metal concentrations from stream waters in two geological blocks in Northern Ireland were compared to determine the contributions of catchment characteristics and in-stream conditions. One block is composed of metamorphosed schist and unconsolidated glacial drift with peat or peaty podzol (mainly humic) soils, while the other block consists of tertiary basalt with brown earth and gley soils. Water samples were collected from 52 stream sites and analysed for $\mathrm{Fe}, \mathrm{Mn}$ and $\mathrm{Al}$ as well as a range of other chemical determinands known to affect metal solubility. Densities of metal-rich ochre deposit were determined for stream bed stone samples. Higher conductivities and concentrations of bicarbonate, alkalinity, Ca and Mg occurred on basalt than on schist. Despite higher Fe and Mn oxide concentrations in basalt-derived non-humic soils, stream water concentrations were much lower and ochre deposit densities only one third of those on schist overlain by humic soils. Neither rock nor soil type predicted $\mathrm{Al}$ concentrations, but $\mathrm{pH}$ and dissolved oxygen did. Peat-generated acidity and the limited acid neutralising capacity of base-poor metamorphosed schist have resulted in elevated concentrations of metals and ochre deposit in surface waters.

\section{Keywords}

Metals · Ochre deposits $\cdot$ Geology $\cdot$ Soil $\cdot \mathrm{pH} \cdot$ Dissolved oxygen 


\section{Introduction}

Orange-brown deposits of iron compounds have been reported from waters in Europe (for example, Åström and Åström 1997; Neal et al. 2008; Prange 2007), North America (Letterman and Mitsch 1978; McKnight and Bencala 1990; Niyogi et al. 1999) and elsewhere (Bray et al. 2008). Many of these are found in post-industrial landscapes and result from acid mine drainage (Kimball et al. 2002; Mayes et al. 2008; Younger 2001). However, stream metal deposits also occur in non-industrial, often upland, environments (Abesser et al. 2006; Prange 2007), frequently resulting from drainage for farming and afforestation (Vuori 1995). These deposits can have harmful effects on algae, invertebrates and fish (Vuori 1995).

The basic chemical processes producing ochre deposits are well known. Mobilisation of $\mathrm{Fe}, \mathrm{Mn}$ and $\mathrm{Al}$, important components of the deposits, is influenced by bedrock weathering, the presence of acidic and/or reducing conditions (Letterman and Mitsch 1978; McKnight and Bencala 1990) and the concentration of dissolved organic carbon (DOC) in the soil (Neal et al. 2010). $\mathrm{Fe}^{2+}$ and $\mathrm{Mn}^{2+}$ are soluble under acidic, reducing conditions, such as those found in poorly buffered catchments and inadequately drained peat soils. In this state these ions can be transported into receiving waterways (Abesser et al. 2006; Neal et al. 2008). However, as $\mathrm{pH}$ increases or conditions become more oxidised in streams, they are converted to insoluble $\mathrm{Fe}^{3+}$ and $\mathrm{Mn}^{4+}$ states, which precipitate onto the stream bed (Mayes et al. 2008; McKnight and Bencala 1990). Aluminium chemistry in natural waters is multifaceted and solubility is strongly linked to $\mathrm{pH}$ and complexation with humic substances (Stutter et al. 2001; Tipping and Carter 2011).

Around 90 to $95 \%$ of the Fe and $\mathrm{Mn}$ found in streams is derived from the surrounding catchment (Durand et al. 1994; Neal et al. 1997; Rowland et al. 2012), with metal concentrations increasing with increased percentage peat cover (for example, Mitchell and McDonald 1995). Naturally occurring sources of catchment acidity include rainwater and organic compounds, such as humic and fulvic acids (Crist et al. 1996; Paciolla et al. 2002; Tipping 2002). Humic acids, and more specifically peat-moss humic acids, are reductant and mobilisation agents (Neal et al. 1997; Paciolla et al. 2002; Rothwell et al. 2008). For example, in the upper River Severn catchment in mid-Wales, Fe is mainly catchment-derived and the highest concentrations were observed under reducing conditions. Stream water Fe concentrations in the catchment have doubled in the last 20 years and are strongly correlated with a rise in soil DOC concentrations (Neal et al. 2008): peat is a major source of DOC 
(Hope et al. 1997). Increased Al concentrations in upland catchments are associated with conifer plantation forestry (Grieve and Marsden 2001; Neal et al. 2010).

Upland catchments in the British Isles tend to experience high annual rainfall as maximum precipitation often occurs at the highest altitudes (Betts 1997; Burt and Ferranti 2012; Hudson et al. 1997) and leaching becomes important where rainfall exceeds evapotranspiration, particularly at altitudes greater than 250 m (Cruickshank 1997; Neal et al. 2010). Catchment geomorphology can strongly influence headwater discharge and chemistry, particularly that of Fe, Mn and DOC (Clark et al. 2008; Neal et al. 2010; Worrall et al. 2006). In upland catchments two distinct sources of Fe and Mn have been identified: organic soilwater and deep soilwater/groundwater (Abesser et al. 2006). The relative contribution of these sources is dependent upon antecedent conditions and storm event magnitude. Metals from organic soilwater tended to dominate during storm events, whereas deep soilwater/groundwater sources were important during periods of low flow (Abesser et al. 2006; Neal et al. 2010). Acidic conditions prevail in headwaters due to the dominance of peat soils with their limited acid neutralising capacity (ANC).

In this study, the role of catchment geology (basalt versus schist and unconsolidated drift) and soil type (humic versus non-humic) on stream water metal concentrations and ochre deposit densities was investigated as part of wider research aimed at determining the ecological effects of ochre deposition on upland stream ecology. Here we document the catchment characteristics and in-stream conditions that potentially determine high metal concentrations and deposit densities in stream systems in two geologically distinct blocks of Northern Ireland. The paper examines a) the influence of geology and soil type on stream metal concentrations and b) the role of stream water $\mathrm{pH}$ and dissolved oxygen (DO) on metal solubility.

\section{Study area}

Bazley (1997) recognised four major geological blocks in Northern Ireland. The Sperrin Mountains form part of the oldest block, of acidic, base-poor, metamorphosed schist, unconsolidated glacial drift and alluvium, while the youngest block, which includes the Antrim plateau, is formed from volcanic lavas and is primarily tertiary basalt (Fig. 1).

Brown earth, podzol, surface water gley, humic ranker, organic alluvium, peat, peaty podzol, surface water humic gley soil types were found in the study site catchments, the last five of which were categorised as humic soils for statistical analysis purposes. Soils in the 
Sperrin Mountains are predominantly peat or peaty podzol (Cruickshank 1997; Mitchell 2004) and extensive areas of bog and moorland dominate slopes. Antrim Plateau soils are mainly brown earths and gleys (Cruickshank 1997).

Climatic conditions in Northern Ireland are mostly wet and mild as a consequence of a mid-latitude position and the influence of the North Atlantic Drift (Betts 1997). Upland areas receive the highest annual precipitation and there is a progressive decline in rainfall levels across the province from west to east. The Sperrin Mountains receive in excess of 1600 mm annually, compared with less than $1300 \mathrm{~mm}$ in the Antrim Plateau (Betts 1997).

\section{Materials and methods}

Sampling and laboratory analysis

Stream water and ochre deposit samples were collected from 52 sites, 35 in the Sperrin Mountains and 17 in the Antrim Plateau in April 2007 (Fig. 1). The study sites, on small (1-2 m wide) upland streams, were chosen because of differing geology, soil type, accessibility and lack of human interference. Ordnance Survey of Northern Ireland topographical and soil maps $(1: 50,000)$ were used to determine altitude, gradient, soil and rock (soil substrate) type. Rock substrates were categorised as basalt and schist/unconsolidated drift, and soils as humic or non-humic. Stream gradient was calculated from elevation changes across contour lines in metres per metre and expressed as a percentage.

Stream water was analysed, in situ, for DO, temperature, conductivity and $\mathrm{pH}$. A HACH HQ 10 portable meter with LDO probe was used to measure DO (\% saturation) and temperature $\left({ }^{\circ} \mathrm{C}\right)$. A HACH sensIONTM 156 portable meter was used to measure conductivity $\left(\mu \mathrm{Sm}^{-1}\right)$ and $\mathrm{pH}$. Probes were calibrated prior to sampling in accordance with $\mathrm{HACH}$ operation manuals. Water samples were collected for dissolved and particulate chemical determinants in clean, $250 \mathrm{ml}$ polypropylene bottles. Bottles were pre-acidified with $2 \mathrm{ml}$ ( \pm 0.1) of $5 \mathrm{M}$ hydrochloric acid per $100 \mathrm{ml}$ of sample to prevent the precipitation and/or sorption of metals. Samples were taken from the centre of the stream channel at approximately $5 \mathrm{~cm}$ below the water surface.

Total, soluble and particulate fractions were determined (in the laboratory) for Fe, $\mathrm{Mn}$, and $\mathrm{Al}$; only total values are presented as all fractions were strongly correlated. Fe, Mn and $\mathrm{Al}$ concentrations were determined by spectrometry using 2, 4, 6-tripyridyl-1, 3, 5- 
triazine, formaldoxime and pyrocatechol violet respectively (HMSO 1978a; 1978b; 1980).

Acid digestion was performed on unfiltered samples according to Eisenreich et al. (1975). Blanks (Millipore Milli-Q) and standards were included, in triplicate, for each chemical determinand.

Ochre deposit material on the upper surface of two to five stones was removed by spatula, brush and rinsing with Millipore Milli-Q grade water. This material was oven dried at $65{ }^{\circ} \mathrm{C}$ until there was no further weight loss. Deposit density was calculated as the mass of material per unit surface area: the latter was determined by covering the upper stone surface with aluminium foil, which was weighed and converted to area.

Tellus Project data

Geochemical data for each of the 52 sites was obtained from the Geological Survey of Northern Ireland Tellus Project. The Tellus project collected soil samples at regular grid intervals of one site per $2 \mathrm{~km}^{2}$ and stream water samples at an average of one site per $2 \mathrm{~km}^{2}$, over the whole land surface of Northern Ireland. Elements and inorganic compounds were analysed using X-ray fluorescence, ion chromatography and inductively coupled plasma (ICP) mass spectrometry. Soil parameters used in this paper were: $\mathrm{pH}$; Calcium (Ca); Magnesium (Mg); Fe and Mn oxide. Water parameters were: $\mathrm{pH}$; conductivity; bicarbonate; alkalinity; Ca; Mg; Fe; Mn; Al and DOC. Tellus data were collected at a different spatial scale and on different dates from our samples, so as a check on comparability correlations between variables measured in common were calculated (conductivity, $\mathrm{pH}, \mathrm{Fe}, \mathrm{Mn}, \mathrm{Al}$ ): the correlation for Al was not significant $(r=0.20)$ but those for the other variables were $(r=$ $0.75-0.86, n=50, P<0.001)$.

\section{Statistical analysis}

Data were tested for normality and with the exception of altitude, $\mathrm{pH}, \mathrm{DO}$ and temperature, variables were $\log _{10}$ transformed: all statistical tests use the transformed data. Relationships between the catchment and stream variables were explored by principal component analysis (PCA), with varimax rotation. Differences between the Sperrin Mountain and Antrim Plateau sites were determined by discriminant analysis; linear regression; general linear modelling (GLM) and analysis of covariance (ANCOVA). Statistical analysis and graphical outputs were generated using the SYSTAT 13 statistical software package. 
Physical and chemical characteristics of the 52 study sites (surveyed in 2007) are summarised in Table 1a. The majority (83\%) of streams in the Sperrin Mountains drain catchments with humic soils overlying schist and unconsolidated drift, whereas on the Antrim Plateau, the dominant rock type is basalt and there is not a preponderance of humic soils (Table 1b). There were significant differences between geological blocks in DO, temperature, $\mathrm{pH}$, conductivity, Fe, Mn and Al. As expected from the geology and soils, stream water conductivity and $\mathrm{pH}$ were higher and $\mathrm{Fe}, \mathrm{Mn}$ and $\mathrm{Al}$ concentrations lower on the Antrim Plateau. These differences are reflected in ochre deposit densities, which were significantly greater in the Sperrin Mountains (medians 6.68, $2.06 \mathrm{mg} \mathrm{cm}^{-2}, P<0.01$ ) (Fig 2). Discriminant analysis correctly allocated all but one of the 52 sites to rock type, by conductivity, $\mathrm{pH}$ and altitude. Humic soils occurred at significantly higher altitudes than non-humic soils (means 260, $194 \mathrm{~m}, F_{1,49}=28.08, P<0.001$ ), but there was no difference across blocks.

All the soil (pH; Ca; Mg; Fe; Mn) and water (pH; conductivity; bicarbonate; alkalinity; Ca; Mg; Fe; Mn; Al; DOC) determinands measured by the Tellus Project (Table 2) differed significantly across rock type. Conductivity and base ion concentrations were two and four times higher for streams located on basalt, as expected from the geology. Soils overlying basalt contained more Fe and Mn than those over schist/unconsolidated drift, yet concentrations of Fe and $\mathrm{Mn}$ in stream water were only $27 \%$ and $10 \%$ of those in the poorly buffered schist sites. Water Fe concentrations increased with DOC in both geological blocks (schist/unconsolidated drift $r=0.46, n=31, P<0.01$; basalt $r=0.77, n=18, P<0.001$ ). However, while DOC concentrations on basalt tended to be $39 \%$ higher, schist/unconsolidated drift sites had 4.0 times the Fe concentrations for a given DOC value (slopes $F_{1,45}=1.20, P>0.2$; intercepts $F_{1,46}=72.92, P<0.001$ ): elevated Fe concentrations in schist/unconsolidated drift streams (Table 2) suggest that DOC does not control Fe mobilisation in this geological block.

Across all sites, metal concentrations in the 2007 stream water survey were negatively correlated with $\mathrm{pH}$ and DO on the first PCA axis, temperature and conductivity with the second axis, while altitude and stream gradient were aligned with the third axis (Table 3a). These relationships were similar in both geological blocks. PCAs of the Tellus Project stream water data (Table 3b) were also consistent across rock type $(r=0.90,0.88, P \leq 0.001$ 
respectively), with the first axis varying with base content/acid neutralising capacity and the second with $\mathrm{pH}, \mathrm{Fe}$ and $\mathrm{Mn}$ concentrations. Note that $\mathrm{Al}$ is more strongly associated with the first axis.

Rock type and soil humic content affected the concentrations of Fe and Mn in stream water, but had no effect on $\mathrm{Al}$ concentrations (Table 4). Streams draining basalt areas had only $40 \%$ of the Fe and $45 \%$ of the Mn concentrations of schist/unconsolidated drift, while streams draining humic soils had higher Fe and Mn concentrations than those from nonhumic soils, by factors of 1.97 and 1.85 respectively. DO levels and $\mathrm{pH}$ negatively affected the concentration of all three metals, particularly $\mathrm{Al}$, in stream water (DO effect for $\mathrm{Mn}, P=$ $0.06)$. Ochre deposit density was also negatively correlated with $\mathrm{DO}$ and $\mathrm{pH}(r=-0.48,-0.49$, $n=50, P<0.001)$.

\section{Discussion}

Anthropogenic influences on the study sites are limited, with only low intensity sheep farming and localised conifer plantation forestry: there is no evidence of mining occurring now or in the past in the study catchments. Hence the geochemical differences that exist between sites reflect variations in catchment geology, soils, topography and climate.

Despite our survey data and the Tellus Project data being collected at different times and different spatial resolution, four of the five determinands common to both datasets were correlated across all sites. In addition to this both datasets showed lower Fe and Mn concentrations in stream waters draining basalt. The differential in stream water concentrations across rock types was somewhat different (Fe 27\%, 40\%; Mn 10\%, 45\% for Tellus project and the 2007 data respectively), but this could simply reflect variations in rainfall levels and throughflow volumes when the samples were collected.

In the literature, concentrations of major ions in stream water are highly correlated with bedrock geology and soil weathering (Robson and Neal 1997; Smart et al. 1998; Thornton and Dise 1998). Basalt is rich in calcium, magnesium and iron oxides (Lutgens and Tarbuck 2008) and the associated soils are characterised by high base status and ANC that maintain circumneutral $\mathrm{pH}$ and high electrical conductivities in surface waters. All soil types analysed in this study were acidic (3.0-5.1): median soil $\mathrm{pH}$ for sites located on basalt was 4.39 compared to 3.43 on schist/unconsolidated drift, a difference of $0.96 \mathrm{pH}$ units. Prange (2007) noted that oxidation of $\mathrm{Fe}^{2+}$ to $\mathrm{Fe}^{3+}$ is accelerated by a factor of 100 if the $\mathrm{pH}$ is raised by one unit. Consequently, higher ANC and less acidic soils on basalt geology reduces metal 
solubility and mobilisation compared to schist/unconsolidated drift. Peat and the limited ANC of base-poor schist has led to acidic conditions and elevated Fe and Mn concentrations in surface waters.

In addition, the predominantly schist dominated Sperrin Mountains, receive more rainfall per annum compared to the basalt rich Antrim Plateau (Cruickshank 1997), which increases the likelihood of metal transport from the catchment. Al concentrations in this study did not differ across rock or soil type, but were more closely associated with pH and DO. Forests are known to increase $\mathrm{Al}$ concentrations in catchments as they actively scavenge acidic oxides from the air (Neal et al. 2010), but few forested areas are present in either geological block: hence variations in $\mathrm{Al}$ concentration are more likely to reflect differing stream water conditions.

\section{Conclusion}

Multiple chemical and biological factors are known to control metal solubility: $\mathrm{pH}$; DO; redox potential; complexing by organic ligands; DOC; presence of ferromanganese depositing bacteria. In this study, catchment and in-stream factors influencing metal concentration and ochre deposit density have been investigated across contrasting geological blocks. Soil type has been highlighted as an important variable in the supply and release of metals from catchments to upland surface waters. Concentrations of Fe and DOC increase in tandem in surface waters as both are largely catchment derived. Stream water metal concentrations decrease with increasing $\mathrm{pH}$ and $\mathrm{DO}$. As conditions become more oxidised and $\mathrm{pH}$ increases, metal solubility decreases, and ochraceous material precipitates onto the stream bed. The effects and implications of rising metal concentrations and ochre deposition in aqueous systems is well documented in the context of acid mine drainage. Nevertheless, research into naturally occurring instances of high stream metal and deposit concentrations is necessary to provide base-line information for non-industrial catchments. 


\section{Acknowledgements}

Katrina Macintosh would like to thank the funding and facilities provided for this study by a Department for Employment and Learning studentship at the University of Ulster. We gratefully acknowledge the Geological Survey of Northern Ireland for providing access to the Tellus Project data set. The Tellus Project was financed by the Department of Enterprise, Trade and Investment and by the Building Sustainable Development Programme (Department of Agriculture and Rural Development) and is reproduced with the permission of the Director of the Geological Survey of Northern Ireland. (c) Crown Copyright (2012). Thanks to Joerg Arnscheidt, Phil Jordan and Brian Rippey for helpful comments on an earlier draft of the manuscript.

\section{References}

Abesser C, Robinson R, Soulsby C (2006) Iron and manganese cycling in the storm runoff of a Scottish upland catchment. J Hydrol 326:59-78. doi:10.1016/j.jhydrol.2005.10.034

Åström M, Åström J (1997) Geochemistry of stream water in a catchment in Finland affected by sulphidic fine sediments. Appl Geochem 12:593-605. doi:10.1016/S08832927(97)00016-4

Bazley RA (1997) Geological background for soil development. In: Cruickshank JG (ed) Soil and environment: Northern Ireland. Agricultural \& Environmental Science Division, DANI and The Agricultural \& Environmental Science Department, The Queen's University of Belfast, Belfast, pp 57-62

Betts NL (1997) Climate. In: Cruickshank JG (ed) Soil and environment: Northern Ireland. Agricultural \& Environmental Science Division, DANI and The Agricultural \& Environmental Science Department, The Queen's University of Belfast, Belfast, pp 6384

Bray JP, Broady PA, Niyogi DK, Harding JS (2008) Periphyton communities in New Zealand streams impacted by acid mine drainage. Mar Freshwater Res 59:1084-1091.

Burt TP, Ferranti EJS (2012) Changing patterns of heavy rainfall in upland areas: a case study from northern England. Int J Climatol 32:518-532. doi:10.1002/joc.2287

Clark JM, Lane SN, Chapman PJ, Adamson JK (2008) Link between DOC in near surface peat and stream water in an upland catchment. Sci Total Environ 404:308-315. doi:10.1016/j.scitotenv.2007.11.002 
Crist RH, Martin JR, Chonko J, Crist DR (1996) Uptake of metals on peat moss: an ionexchange process. Environ Sci Technol 30:2456-2461. doi:10.1021/es950569d Cruickshank JG (ed) (1997) Soil and environment: Northern Ireland. Agricultural \& Environmental Science Division, DANI and The Agricultural \& Environmental Science Department, The Queen's University of Belfast, Belfast

Durand P, Neal C, Jeffery HA, Ryland GP, Neal M (1994) Major, minor and trace element budgets in the Plynlimon afforested catchments (Wales): general trends, effects of felling and of climate variations. J Hydrol 157:139-156. doi:10.1016/00221694(94)90102-3

Eisenreich SJ, Bannerman RT, Armstrong DE (1975) A simplified phosphorus analysis technique. Environ Lett 9:43-53

Grieve I, Marsden RL (2001) Effects of forest cover and topographic factors on TOC and associated metals at various scales in western Scotland. Sci Total Environ 265:143-151. doi:10.1016/S0048-9697(00)00655-0

HMSO (1978a) Iron in raw and potable waters by spectrophotometry (using 2, 4, 6tripyridyl-1, 3, 5-triazine). Her Majesty’s Stationery Office, London

HMSO (1978b) Manganese in raw and potable waters by spectrophotometry (using formaldoxime). Her Majesty’s Stationery Office, London

HMSO (1980) Aluminium in raw and potable waters by spectrophotometry (using pyrocatechol violet). Her Majesty’s Stationery Office, London

Hope D, Billett MF, Milne R, Brown TAW (1997) Exports of organic carbon in British rivers. Hydrol Process 11:325-344.

Hudson JA, Crane SB, Blackie JR (1997) The Plynlimon water balance 1969-1995: the impact of forest and moorland vegetation on evaporation and stream flow in upland catchments. Hydrol Earth Syst Sc 1:409-427

Kimball BA, Runkel RL, Walton-Day K, Bencala KE (2002) Assessment of metal loads in watersheds affected by acid mine drainage using tracer injection and synoptic sampling: Cement Creek, Colorado, USA. Appl Geochem 17:1183-1207.

Letterman RD, Mitsch WJ (1978) Impact of mine drainage on a mountain stream in Pennsylvania. Environ Pollut 17:53-73

Lutgens FK, Tarbuck EJ (2008) Foundations of earth science. 5th ed edn. Pearson Education International, London 
Mayes WM, Gozzard E, Potter HAB, Jarvis AP (2008) Quantifying the importance of diffuse minewater pollution in a historically heavily coal mined catchment. Environ Pollut 151 165-175. doi:10.1016/j.envpol.2007.02.008

McKnight DM, Bencala KE (1990) The chemistry of iron, aluminium, and dissolved organic material in three acidic, metal-enriched mountain streams, as controlled by watershed and in-stream processes. Water Resour Res 26:3087-3100

Mitchell G, McDonald AT (1995) Catchment characterization as a tool for upland water quality management. J Environ Manage 44:83-95.

Mitchell WI (ed) (2004) The geology of Northern Ireland our national foundation. 2nd edn. Geological Survey of Northern Ireland, Belfast

Neal C, Lofts S, Evans CD, Reynolds B, Tipping E, Neal M (2008) Increasing iron concentrations in UK upland waters. Aquat Geochem 14:263-288. doi:10.1007/s10498008-9036-1

Neal C, Robinson M, Reynolds B, Neal M, Rowland P, Grant S, Norris D, Williams B, Sleep D, Lawlor A (2010) Hydrology and water quality of the headwaters of the River Severn: Stream acidity recovery and interactions with plantation forestry under an improving pollution climate. Sci Total Environ 408:5035-5051. doi:10.1016/j.scitotenv.2010.07.047

Neal C, Wilkinson J, Neal M, Harrow M, Wickham H, Hill L, Morfitt C (1997) The hydrogeochemistry of the headwaters of the river Severn, Plynlimon. Hydrol Earth Syst Sc 1:583-618

Niyogi DK, McKnight DM, Lewis WM (1999) Influences of water and substrate quality for periphyton in a montane stream affected by acid mine drainage. Limnol Oceanogr 44:804-809.

Paciolla MD, Kolla S, Jansen SA (2002) The reduction of dissolved iron species by humic acid and subsequent production of reactive oxygen species. Adv Environ Res 7:169178. doi:10.1016/S1093-0191(01)00129-0

Prange H (2007) Ochre pollution as an ecological problem in the aquatic environment: solution attempts from Denmark. Edmund Siemers-Stiftung, Hamburg

Robson AJ, Neal C (1997) A summary of regional water quality for eastern UK rivers. Sci Total Environ 194 15-37. doi:10.1016/S0048-9697(96)05351-X

Rothwell JJ, Evans MG, Allott TEH (2008) In-stream processing of sediment-associated metals in peatland fluvial systems. Water Air Soil Poll 187:53-64. doi:10.1007/s11270007-9496-8 
Rowland AP, Neal C, Reynolds B, Neal M, Lawlor AJ, Sleep D (2012) Manganese in the upper Severn mid-Wales. J Environ Monit 14:155-164. doi:10.1039/C1EM10651A

Smart RP, Soulsby C, Neal C, Wade AJ, Cresser MS, Billett MF, Langan SJ, Edwards AC, Jarvie HP, Owen R (1998) Factors regulating the spatial and temporal distribution of solute concentrations in a major river system in N.E. Scotland. Sci Total Environ 221:93-110. doi:10.1016/S0048-9697(98)00196-X

Stutter M, Smart R, Cresser M, Langan S (2001) Catchment characteristics controlling the mobilization and potential toxicity of aluminium fractions in the catchment of the River Dee, northeast Scotland. Sci Total Environ 281:121-139. doi:10.1016/S00489697(01)00841-5

Thornton GJP, Dise NB (1998) The influence of catchment characteristics, agricultural activities and atmospheric deposition on the chemistry of small streams in the English Lake District. Sci Total Environ 216:63-75. doi:10.1016/S0048-9697(98)00138-7

Tipping E (2002) Cation binding by humic substances. Cambridge University Press, Cambridge

Tipping E, Carter HT (2011) Aluminium speciation in streams and lakes of the UK Acid Water Monitoring Network, modelled with WHAM. Sci Total Environ 409:1550-1558. doi:10.1016/j.scitotenv.2010.12.030

Vuori K-M (1995) Direct and indirect effects of iron on river ecosystems. Ann Zool Fenn 32:317-329.

Worrall F, Burt TP, Adamson J (2006) The rate of and controls upon DOC loss in a peat catchment. J Hydrol 321:311-325. doi:10.1016/j.jhydrol.2005.08.019

Younger PL (2001) Mine water pollution in Scotland: nature, extent and preventative strategies. Sci Total Environ 265:309-326. doi:10.1016/S0048-9697(00)00673-2 
390 Fig. 1 Topographic map showing the location of the 52 study sites (black dots) within

391 Northern Ireland. The thick solid lines delimit the four geological blocks identified by Bazley 392 (1997)

393

394 Fig. 2 Histograms showing the concentrations $\left(\mathrm{mg} \mathrm{cm}^{-2}\right)$ of ochraceous deposits on stones in 395 the Antrim Plateau: basalt; non-humic soil (dark shading) and Sperrin Mountains: schist; 396 humic soil (light shading)

397 


\section{$398 \quad$ Figures}

399

400

Fig. 1

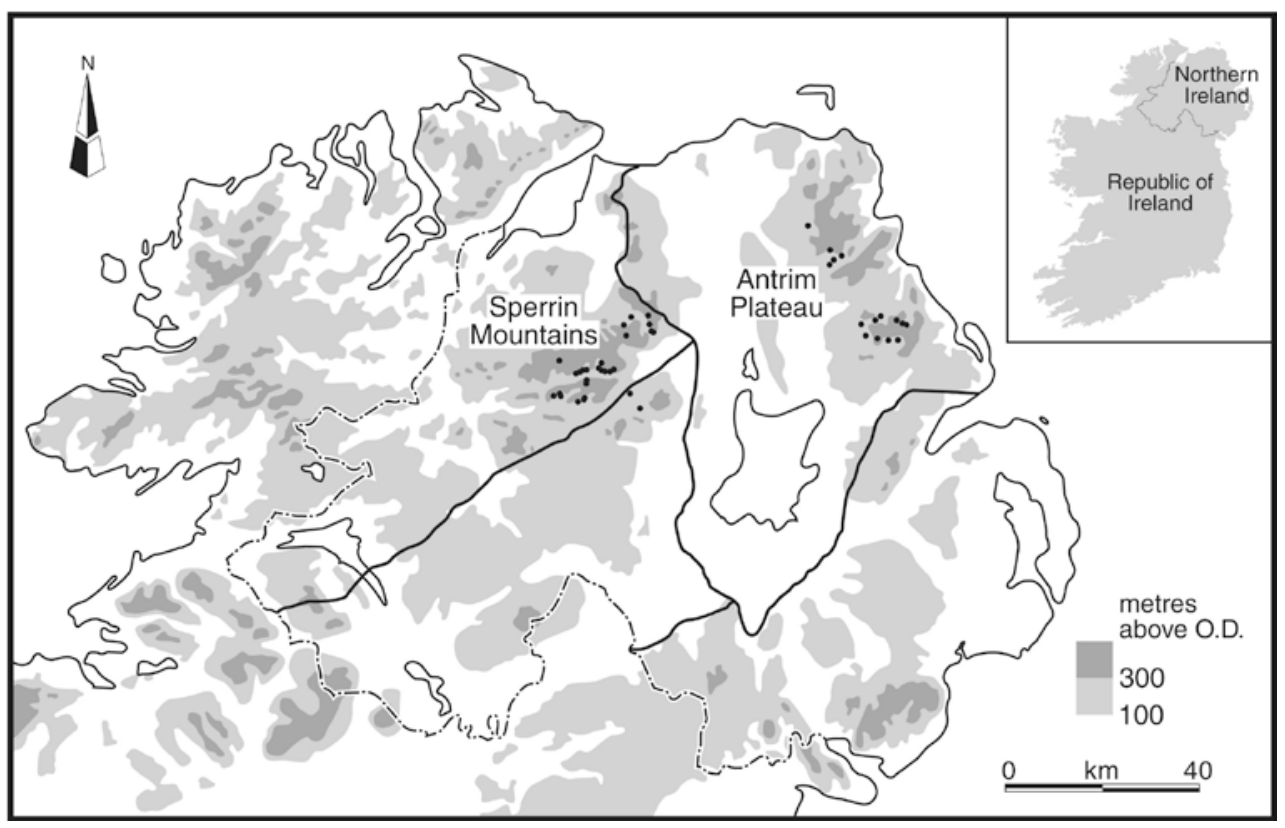

402 
403

Fig. 2

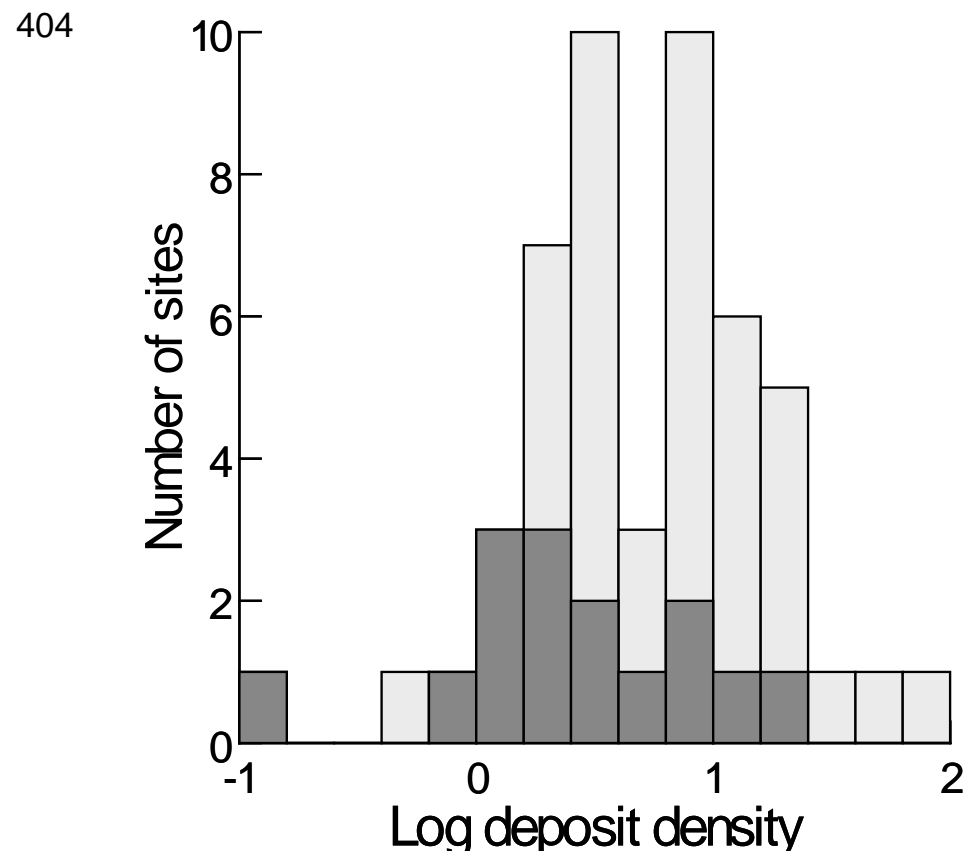


405 Table 1 (a) Summary of the physical and chemical characteristics of the 52 streams surveyed 406 in 2007 and (b) distribution of soil and rock types in the catchments of the streams sampled. 407 Differences in the medians between geological blocks were tested using the Mann-Whitney 408 test

409

$410 \quad$ (a)

\begin{tabular}{|c|c|c|c|c|c|c|c|}
\hline & \multicolumn{4}{|c|}{ Sperrin sites $(n=35)$} & \multicolumn{3}{|c|}{ Antrim sites $(n=17)$} \\
\hline & Minimum & Maximum & Median & & Minimum & Maximum & Median \\
\hline Altitude (m) & 175 & 360 & 235 & & 155 & 305 & 240 \\
\hline Gradient (\%) & 0.59 & 10.00 & 3.64 & & 0.80 & 6.67 & 2.86 \\
\hline \% DO & 55 & 111 & 101 & $*$ & 76 & 118 & 104 \\
\hline Temperature $\left({ }^{\circ} \mathrm{C}\right)$ & 6.0 & 11.9 & 9.4 & $* *$ & 6.2 & 10.8 & 7.7 \\
\hline $\mathrm{pH}$ & 6.3 & 7.8 & 7.4 & $* * *$ & 6.8 & 8.6 & 8.0 \\
\hline Conductivity $\left(\mu \mathrm{S} \mathrm{cm}^{-1}\right)$ & 65 & 258 & 94 & $* * *$ & 220 & 351 & 273 \\
\hline $\mathrm{Fe}\left(\mathrm{mg} \mathrm{L}^{-1}\right)$ & 0.011 & 10.772 & 1.408 & $* * *$ & 0.052 & 9.887 & 0.253 \\
\hline $\operatorname{Mn}\left(\mathrm{mg} \mathrm{L}^{-1}\right)$ & 0.023 & 1.590 & 0.390 & $* * *$ & 0.038 & 0.720 & 0.105 \\
\hline $\mathrm{Al}\left(\mathrm{mg} \mathrm{L}^{-1}\right)$ & 0.018 & 0.939 & 0.086 & $* *$ & 0.018 & 0.465 & 0.030 \\
\hline
\end{tabular}




Basalt Gravel Alluvium Schist Totâl

Sperrin sites

\begin{tabular}{lccccc} 
Humic soils & 1 & 2 & 14 & 12 & 29 \\
Non-humic soils & 1 & 4 & 0 & 1 & 6 \\
\hline Total & 2 & 6 & 14 & 13 & 35
\end{tabular}

Antrim sites

\begin{tabular}{lccccc} 
Humic soils & 8 & 0 & 1 & 0 & 9 \\
Non-humic soils & 8 & 0 & 0 & 0 & 8 \\
\hline Total & 16 & 0 & 1 & 0 & 17
\end{tabular}

415

416 
417 Table 2 Tellus Project data median soil and stream water parameters for the 52 sample sites 418 and the ratios between schist/unconsolidated drift:basalt rocks. All values are significantly 419 different between rock-type (Mann-Whitney test, $P<0.05$ )

420

\begin{tabular}{lccc}
\hline & Schist/unconsol. drift & Basalt & Ratio \\
\hline Soil & 3.43 & & \\
pH & 0.57 & 1.39 & 1.28 \\
Ca oxide (\%) & 0.80 & 1.29 & 2.73 \\
Mg oxide (\%) & 2.05 & 5.32 & 2.62 \\
Fe oxide (\%) & 0.03 & 0.08 & 3.37 \\
Mn oxide (\%) & & &
\end{tabular}

Water

\begin{tabular}{lrrr}
$\mathrm{pH}$ & 7.10 & 7.92 & 1.12 \\
Conductivity $\left(\mu \mathrm{S} \mathrm{cm}^{-1}\right)$ & 72.95 & 167.88 & 2.30 \\
Bicarbonate $\left(\mathrm{mg} \mathrm{L}^{-1}\right)$ & 20.65 & 93.97 & 4.55 \\
Alkalinity $\left(\mathrm{mg} \mathrm{L}^{-1}\right)$ & 20.14 & 76.91 & 3.82 \\
$\mathrm{Ca}\left(\mathrm{mg} \mathrm{L}^{-1}\right)$ & 5.20 & 16.48 & 3.17 \\
$\mathrm{Mg}\left(\mathrm{mg} \mathrm{L}^{-1}\right)$ & 2.21 & 10.91 & 4.93 \\
Fe $\left(\mathrm{mg} \mathrm{L}^{-1}\right)$ & 1.43 & 0.38 & 0.27 \\
$\mathrm{Mn}\left(\mathrm{mg} \mathrm{L}^{-1}\right)$ & 213.80 & 20.56 & 0.10 \\
$\mathrm{Al}\left(\mathrm{mg} \mathrm{L}^{-1}\right)$ & 101.62 & 83.95 & 0.83 \\
$\mathrm{DOC}\left(\mathrm{mg} \mathrm{L}^{-1}\right)$ & 11.12 & 15.42 & 1.39 \\
\hline
\end{tabular}


423 Table 3 Varimax-rotated PCA component loadings for (a) the 2007 survey data across all 424 sites and (b) the Tellus Project stream water data for each rock type. Significant loadings are 425 shown in bold

426

$427 \quad$ (a)

\begin{tabular}{llll}
\hline & Factor 1 & Factor 2 & Factor 3 \\
\hline Altitude & 0.15 & $\mathbf{- 0 . 3 9}$ & $\mathbf{0 . 7 7}$ \\
Gradient & -0.22 & 0.23 & $\mathbf{0 . 6 9}$ \\
DO & $\mathbf{- 0 . 7 3}$ & 0.12 & 0.24 \\
Temperature & 0.03 & $\mathbf{0 . 8 9}$ & -0.13 \\
pH & $\mathbf{- 0 . 8 4}$ & -0.13 & 0.18 \\
Conductivity & $\mathbf{- 0 . 4 0}$ & $\mathbf{- 0 . 7 6}$ & -0.16 \\
Fe & $\mathbf{0 . 9 1}$ & 0.22 & 0.02 \\
Mn & $\mathbf{0 . 8 7}$ & $\mathbf{0 . 2 7}$ & 0.18 \\
Al & $\mathbf{0 . 9 3}$ & 0.05 & 0.03 \\
\hline \% variance & 43 & 19 & 14 \\
\hline
\end{tabular}


430 (b)

\begin{tabular}{lcccc}
\hline & \multicolumn{2}{l}{ Schist/unconsol. drift } & Basalt \\
\cline { 2 - 5 } & Factor 1 & Factor 2 & Factor 1 & Factor 2 \\
\hline Conductivity & $\mathbf{0 . 6 4}$ & 0.14 & $\mathbf{0 . 9 5}$ & 0.30 \\
Bicarbonate & $\mathbf{0 . 8 8}$ & 0.30 & $\mathbf{0 . 9 3}$ & 0.34 \\
Alkalinity & $\mathbf{0 . 4 1}$ & $\mathbf{- 0 . 3 8}$ & $\mathbf{0 . 9 3}$ & 0.34 \\
Ca & $\mathbf{0 . 8 9}$ & 0.21 & $\mathbf{0 . 9 3}$ & 0.33 \\
Mg & $\mathbf{0 . 8 7}$ & 0.31 & $\mathbf{0 . 9 4}$ & 0.27 \\
pH & $\mathbf{0 . 3 8}$ & $\mathbf{0 . 7 6}$ & $\mathbf{0 . 6 0}$ & $\mathbf{0 . 6 3}$ \\
Fe & -0.18 & $\mathbf{- 0 . 8 3}$ & -0.41 & $\mathbf{- 0 . 8 1}$ \\
Mn & -0.24 & $\mathbf{- 0 . 7 7}$ & 0.04 & $\mathbf{- 0 . 9 6}$ \\
Al & $\mathbf{- 0 . 5 5}$ & 0.24 & $\mathbf{- 0 . 9 3}$ & -0.05 \\
DOC & 0.14 & $\mathbf{- 0 . 7 7}$ & -0.46 & $\mathbf{- 0 . 7 1}$ \\
\hline \% variance & 35 & 29 & 60 & 30 \\
\hline
\end{tabular}

431 
Table 4 (a) GLM results for catchment rock and soil type effects on the ( $\left.\log _{10}\right)$

434 concentrations of $\mathrm{Fe}, \mathrm{Mn}$ and $\mathrm{Al}$ in stream waters in the 2007 survey and (b) least squares

435 adjusted means

436

437

(a)

\begin{tabular}{|c|c|c|c|c|c|c|c|c|c|}
\hline & $\mathrm{Fe}$ & & & Mn & & & $\mathrm{Al}$ & & \\
\hline Source & $\mathrm{df}$ & MS & $F$ & $\mathrm{df}$ & MS & $F$ & $\mathrm{df}$ & MS & $F$ \\
\hline Rock type & 1 & 0.905 & $11.30 * *$ & 1 & 0.737 & $15.54^{* * *}$ & 1 & 0.088 & 1.77 \\
\hline Soil humic content & 1 & 0.719 & $8.98 * *$ & 1 & 0.624 & $13.15^{* * *}$ & 1 & 0.125 & 2.51 \\
\hline DO & 1 & 0.450 & $5.62 *$ & 1 & 0.174 & 3.67 & 1 & 0.536 & $10.75^{* *}$ \\
\hline $\mathrm{pH}$ & 1 & 0.392 & $4.90 *$ & 1 & 0.217 & $4.57^{*}$ & 1 & 0.410 & $8.22 * *$ \\
\hline Error & 45 & 0.080 & & 46 & 0.047 & & 45 & 0.050 & \\
\hline$R^{2}$ & & 0.73 & & & 0.73 & & & 0.68 & \\
\hline
\end{tabular}

$* P<0.05, * * P<0.01, * * * P<0.001$

439

$440 \quad$ (b)

441 Least squares adjusted means

\begin{tabular}{lllllll}
\hline & Fe & & Mn & & Al \\
& Mean \pm se & $n$ & Mean \pm se & $n$ & Mean \pm se & $n$ \\
\hline Basalt & $-0.421 \pm 0.086$ & 17 & $-0.860 \pm 0.062$ & 18 & $-1.320 \pm 0.063$ & 18 \\
Schist/unconsol. drift & $-0.024 \pm 0.065$ & 33 & $-0.517 \pm 0.050$ & 33 & $-1.201 \pm 0.052$ & 32 \\
& & & & & & \\
Humic & $-0.076 \pm 0.053$ & 37 & $-0.555 \pm 0.041$ & 37 & $-1.321 \pm 0.061$ & 36 \\
Non-humic & $-0.370 \pm 0.081$ & 13 & $-0.823 \pm 0.059$ & 14 & $-1.200 \pm 0.042$ & 14 \\
\hline
\end{tabular}

